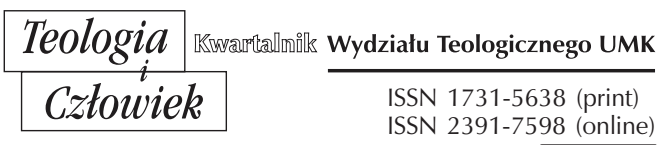

56(2021)4, ss. 95-112

JOLANTA KUROSZ

UNIWERSYTET IM. ADAMA MICKIEWICZA W POZNANIU

KUROSZ@AMU.EDU.PL

ORCID 0000-0002-2991-790X

KS. TOMASZ WIELEBSKI

UNIWERSYTET KARDYNAŁA STEFANA WYSZYŃSKIEGO W WARSZAWIE

TOMWIELEBSKI@GMAIL.COM

ORCID 0000-0002-1313-8514

\title{
FORMACJA PASTORALNOTEOLOGICZNA KLERYKÓW W ŚWIETLE „RATIO INSTITUTIONIS SACERDOTALIS PRO POLONIA" Z 2021 ROKU
}

DOI: http://dx.doi.org/10.12775/TiCz.2021.029

Streszczenie. Obowiązujący od 1 października 2021 roku dokument Droga formacji prezbiterów w Polsce. Ratio institutionis sacerdotalis pro Polonia staje się bodźcem do postawienia pytania o to, jak powinna wyglądać formacja pastoralnoteologiczna kleryków w seminariach w Polsce. Dokument, wskazując na konieczność integralności całej formacji kandydatów do kapłaństwa, zwraca uwagę, że ma ona być osiągnięta przez harmonijne powiązanie czterech jej wymiarów: ludzkiego, duchowego, intelektualnego i duszpasterskiego, podkreślając konieczność jej nachylenia duszpasterskiego (por. RISP 74; 80; 463). Prowadzone rozważania zawarto w trzech punktach. Po przedstawieniu celu formacji (1) ukazano jej etapy (2), a następnie podjęto refleksję nad całym procesem kształcenia dokonującym się w jej ramach (3).

Słowa kluczowe: Ratio institutionis sacerdotalis pro Polonia (2021); formacja pastoralnoteologiczna; klerycy; seminaria duchowne.

Abstract. Pastoral-Theological Formation of Clerics in the Context of the $R \boldsymbol{a}$ tio institutionis sacerdotalis pro Polonia (2021). The document entitled The formation 
process of presbyters in Poland. Ratio institutionis sacerdotalis pro Polonia, in force since October 1, 2021, has provided an impulse to pose the question of what the pastoral-theological formation of clerics attending seminaries in Poland should look like. The document emphasizes the need to ensure the integrity of the entire formation of candidates for priesthood and points out that it is to be achieved by the harmonious coordination of the human, spiritual, intellectual and pastoral dimensions, which must be accompanied by a pastoral inclination (cf. RISP 74; 80; 463). The author presents his considerations in three sections. He begins by describing the purpose of the formation (1), then discusses its stages (2) and, finally, reflects on the entire educational process that takes place as part of the formation (3).

Key words: Ratio institutionis sacerdtotalis pro Polonia (2021); pastoral-theological formation; clerics; seminaries.

Obowiązujący od 1 października 2021 roku dokument Droga formacji prezbiterów w Polsce. Ratio institutionis sacerdotalis pro Polonia stał się bodźcem do postawienia pytania o to, jak powinna wyglądać formacja pastoralnoteologiczna kleryków w seminariach w Polsce. Trzeba w tym kontekście przypomnieć nauczanie dekretu soborowego o formacji kapłańskiej Optatam totius, który podkreślał konieczność nadawania całemu wychowywaniu alumnów wymiaru duszpasterskiego ${ }^{1}$. Rozwijając nauczanie soborowe, Jan Paweł II w adhortacji Pastores dabo vobis, pisząc o czterech wzajemnie powiązanych ze sobą wymiarach formacji kapłańskiej: ludzkim, duchowym, intelektualnym i duszpasterskim, podkreślał konieczność jej nachylenia duszpasterskiego, zwracając zarazem uwagę na pastoralność całej teologii ${ }^{2}$. Nowe Ratio wpisuje się w ten nurt nauczania, przestrzega przed jej separowaniem i autonomizacją, podkreślając zarazem jej charakter pastoralny ${ }^{3}$. Warto przy tym zauważyć, że autorzy omawiając formację seminaryjną kleryków, podkreślają jej charakter pastoralny i traktują ją jako pierwszy etap w stałej formacji prezbiterów (por. RISP 23; 377-378).

1 Por. Sobór Watykański II, Dekret o soborowej formacji kapłańskiej Optatam totius, Watykan 1965, nr 19-21 (dalej skrót: DFK).

2 Por. Jan Paweł II, Adhortacja apostolska Pastores dabo vobis, Watykan 1992, nr 55; 57 (dalej skrót: PDV).

3 Droga formacji prezbiterów $w$ Polsce. Ratio institutionis sacerdtotalis pro Polonia, Warszawa2021,74;80,https://episkopat.pl/wp-content/uploads/2021/06/20210616Droga-formacji-prezbiterów-w-Polsce.pdf [data dostępu: 25.07.2021] (dalej skrót: RISP). 
Przywoływane dokumenty Magisterium, wskazując na konieczność duszpasterskiego nachylenia całej formacji, używają zasadniczo terminu formacja pastoralna lub formacja duszpasterska. Ks. prof. Ryszard Kamiński, nestor polskich teologów pastoralistów, w swoim artykule poświęconym formacji duszpasterskiej kleryków używa tego pojęcia zamiennie z pojęciem edukacja pastoralnoteologiczna, podkreślając, że podstawa programowa dla teologii pastoralnej „musi mieć wymiar duszpasterski i opierać się na nauczaniu Kościoła współczesnego"'. Poza tym, istotną kwestią w tym procesie jest nie tylko zdobycie wiedzy i umiejętności przez kleryków, ale także zmiana nastawienia, sposobu myślenia, a przede wszystkim wewnętrznego przekonania o konieczności wykorzystania w posłudze duszpasterskiej owoców prowadzonej refleksji naukowej.

Autorzy artykułu, nawiązując do adhortacji Pastores dabo vobis, w której Jan Paweł II scharakteryzował teologię pastoralną jako „naukową refleksją o codziennym wzrastaniu Kościoła w mocy Ducha Świętego w kontekście historii”, podkreślając, że „nie jest tylko umiejętnością, zespołem wskazań, doświadczeń i metod”, ale „ma status pełnoprawnej dyscypliny teologicznej, ponieważ czerpie z wiary zasady i kryteria działalności duszpasterskiej” (PDV 57), postanowili używać określenia formacja pastoralnoteologiczna, które znajduje się także w nowym Ratio (por. RISP 523). Warto zaznaczyć, że formacja obejmuje wykłady, ćwiczenia i praktyki duszpasterskie, czyli cały proces dydaktyczny prowadzący „do naukowego ukształtowania świadomości istoty i zbawczego posłannictwa aktualnie działającego Kościoła, który realizuje w konkretnych warunkach swoją misję zbawczą" (RISP 523). Za użyciem takiego terminu przemawia także nauczanie Jana Pawła II mówiące o przeznaczeniu duszpasterskim, czyli pastoralności całej teologii, na co zwraca też uwagę Ratio (por. PDV 55; RISP 463).

Autorzy artykułu, odwołując się do dokumentu, stawiając sobie za cel poszukiwanie odpowiedzi na pytanie o kształt i sposób realizacji formacji pastoralnoteologicznej kleryków, podejmą swoją refleksję w trzech punktach. W pierwszym przedstawią cel tej formacji, a w drugim jej kolejne etapy. Punkt trzeci zawierać będzie refleksję nad całym procesem kształcenia dokonującym się w jej ramach.

${ }^{4}$ R. Kamiński, Formacja duszpasterska kleryków w wyższych seminariach duchownych, „Homo Dei” 1 (2021), s. 101. 


\section{CEL FORMACJI}

Podejmując zagadnienie formacji pastoralnoteologicznej kleryków, trzeba najpierw określić jej cel. Powinna ona być widziana w perspektywie tożsamości prezbiterów ${ }^{5}$ związanej z priorytetowym uznawaniem płaszczyzny sakramentalnoontycznej rozumianej jako ich wszczepienie w Chrystusa i Jego Kościół. Wspomniana tożsamość, związana z charakterem sakramentalnym posługi kapłańskiej realizowanej in persona Christi, wyznacza punkt dojścia całej formacji seminaryjnej, co pozwala uniknąć funkcjonalnego rozumienia prezbiteratu sprowadzanego jedynie do wykonywania zawodu księdza (por. RISP 32; 34). Autorzy Ratio, wyjaśniając istotę formacji, podkreślają, że „zasadnicza jej idea polega na tym [...], by formować uczniów misjonarzy «zakochanych» w Nauczycielu, pasterzy «o zapachu owiec», którzy żyją pośród nich, aby im służyć i nieść im Boże miłosierdzie" (RISP 4). Według nich naczelną cechą duchowości oraz zasadą ożywiającą i kierującą życiem prezbiterów ma być miłość pasterska wyrażająca się w naśladowaniu Jezusa Dobrego Pasterza, chroniącą przed klerykalizmem i pragnieniem panowania nad owczarnią oraz demokratyzmem (por. RISP 44).

Autorzy Ratio podkreślają, że cała droga formacyjna prezbiterów, obejmująca również formację seminaryjną, ma odznaczać się jednością, wspólnotowością, misyjnością i integralnością (por. RISP 69-73). Integralność można osiągnąć przez harmonijną realizację jej czterech, współzależnych od siebie, wymiarów: ludzkiego, duchowego, intelektualnego oraz pastoralnego (por. RISP 74-80). Wszyscy wykładowcy seminaryjni powinni prowadzić zajęcia, zachowując formacyjny i pastoralny charakter studiów, mając świadomość ścisłej relacji między wspomnianymi czterema wymiarami formacji (por. RISP 207). Warto zauważyć, że autorzy poruszając kwestię formacji seminarzystów, zwracają też uwagę na rolę wiernych świeckich, podkreślając wychowawczą rolę kobiet oraz osób konsekrowanych. To od nich seminarzyści mogą się uczyć doceniania różnych powołań, darów i charyzmatów obecnych w Kościele i nabywania wobec tych

5 Por. Benedykt XVI, Przemówienie do uczestników sympozjum teologicznego zorganizowanego przez Kongregację ds. Duchowieństwa Kapłaństwo wymaga radykalnej ciągłości między formacją seminaryjną a formacją stałą, Watykan 12.03.2010, „L'Osservatore Romano" 5 (2010), s. 35. 
osób duszpasterskiej wrażliwości (por. RISP 213). Ukierunkowanie pastoralne, które ma przenikać pozostałe wymiary formacji, domaga się przygotowania specyficznie duszpasterskiego przyszłych prezbiterów, formując ich do „misji i towarzyszenia, rozeznawania i służby, współpracy i przewodzenia w Kościele" (RISP 80). Ponadto prowadzący formację pastoralnoteologiczną muszą brać pod uwagę wyzwania nowej ewangelizacji, uwzględniając w jej prowadzeniu różne kategorie osób: żyjących gorliwie wiarą, zagubionych oraz niewierzących. Autorzy Ratio, podkreślając konieczność uwzględnienia $\mathrm{w}$ formacji pastoralnej powyższych kategorii osób, nawiązują do adhortacji Franciszka Evangelii gaudium, zauważając, że w formacji pastoralnej trzeba uwzględnić w pierwszym rzędzie wprowadzenie kandydatów w obszar apostolstwa zwyczajnego, obejmującego również wiernych deklarujących swój katolicyzm, niebiorących udziału w publicznym kulcie. W dokumencie zwrócono uwagę też na konieczność przygotowywania kleryków do pracy z szeroką kategorią osób ochrzczonych nieżyjących zgodnie $\mathrm{z}$ wymaganiami tego sakramentu, jak też nieznających Jezusa oraz Go odrzucających (por. RISP 80). W formacji pastoralnej trzeba uwrażliwiać seminarzystów na osoby będące poza owczarnią Kościoła, ucząc ich postawy wyjścia również do osób innych tradycji religijnych, obojętnych oraz niewierzących w Boga (por. RISP 80).

Trzeba zauważyć, że autorzy Ratio, wskazując na całościową rolę teologii w kształtowaniu tożsamości prezbitera i podkreślając, że w ciągu wieków rozwijała się ona jako nauka służąca w szczególny sposób duszpasterstwu, stwierdzają, że istotne jest uprawianie jej dalej „w tym samym duchu" (RISP 463). Ponadto praktyczny wymiar teologii powinien być uwzględniony w kształtowaniu tożsamości i aktywności pastoralnej prezbiterów oraz ich twórczej obecności w świecie i angażowania się w jego sprawy, tworząc razem z filozofią kulturę wiary, służąc tajemnicy zbawienia i utrwalając integralną racjonalność w życiu człowieka (por. RISP 463).

\section{ETAPY FORMACJI}

Po przedstawieniu celu formacji pastoralnoteologicznej kleryków, zostaną teraz przedstawione jej etapy. W Ratio formacja seminaryjna została podzielona na cztery etapy: „etap propedeutyczny”, „etap stawania 
się uczniem Jezusa”, „etap upodabniania się do Chrystusa” oraz „etap pastoralny" (RISP 254). W dokumencie podkreślono, że kolejne etapy formacji „są ze sobą powiązane”, tworząc wspólną drogę, zauważono, że podążanie nią ma umożliwić „stopniowe dojrzewanie seminarzystów we wszystkich wymiarach formacji” (RISP 254).

Etap propedeutyczny, będący czasem podstawowego rozeznania i wyboru drogi formacji, ma przede wszystkim dostarczyć seminarzystom podstaw pod życie duchowe i pomóc im w formacji ludzkiej (por. RISP 261). Ważnym przyczynkiem do rozwoju osobowego ma być wolontariat sprzyjający poznawaniu samego siebie, ofiarowywaniu się innym i budowaniu międzyludzkich relacji. Ma się to dokonywać w ramach praktyk realizowanych w parafiach i innych środowiskach posługi wobec osób chorych, biednych i starszych w szpitalach, hospicjach, domach opieki społecznej, ośrodkach dla dzieci z niepełnosprawnością. Autorzy Ratio podkreślając, że należy uprzednio zapoznać seminarzystów z podstawowymi informacjami dotyczącymi specyfiki tych ośrodków, zauważają, że praktyki realizowane na tym etapie nie powinny się wiązać z ich odpowiedzialnością pastoralną (por. RISP 278).

Kolejny etap formacji seminaryjnej, zwany etapem stawania sie uczniem Jezusa, ma być czasem weryfikacji motywacji powołania i kształtowania się tożsamości ucznia Chrystusa Nauczyciela, co jest związane $\mathrm{z}$ etapem formacji filozoficzno-humanistycznej (por. RISP 282; 291). Patrząc na miejsce filozofii w formacji pastoralnoteologicznej dokonywanej na tym etapie, trzeba za dokumentem podkreślić, że ma ona formować przyszłych ewangelizatorów, pomagając im w zrozumieniu współczesnej kultury, dominujących stylów myślenia i aktualnych aspiracji i zagrożeń występujących w życiu społeczeństw. Jej studiowanie ma też wdrażać do dialogu, ucząc wsłuchiwania się w różne przekonania ludzi oraz stojące za nimi racje, pomagając zarazem w ich zobiektywizowanej ocenie i umożliwiając krytyczny udział we współczesnej kulturze i w życiu społecznym, którego podstawowym elementem jest podejmowanie misji ewangelizacyjnej (por. RISP 430). Ważnym elementem tego etapu mają też być realizowane w ciągu roku akademickiego i wyjazdów wakacyjnych praktyki duszpasterskie w parafiach, mediach, więzieniach, domach samotnej matki, szpitalach, hospicjach. Podkreśla się, że powyższe praktyki, realizowane po zdobyciu odpowiedniego przygotowania i pod opieką wyznaczo- 
nego duszpasterza, mają z jednej strony służyć integralnemu rozwojowi kleryków, a z drugiej zdobywaniu doświadczeń pastoralnych i poznawaniu różnorodności społeczno-charytatywnych, jak i ewangelizacyjnych działań duszpasterskich Kościoła (por. RISP 294).

Zorientowany ku sakramentowi święceń „etap upodabniania się do Chrystusa Pasterza”, powiązany ze studium teologii, jest środkiem do zrozumienia tożsamości, duchowości i misji prezbitera (por. RISP 300; 303; 308). Autorzy Ratio, wskazując na konieczność wypracowywania przez seminarzystów właściwej, odrzucającej klerykalizm, postawy wobec Kościoła, zwracają uwagę na rolę „eklezjologii i wynikających z niej zasad postępowania pasterskiego" (RISP 306). Podkreślają, że na tym etapie w czasie wykładów i ćwiczeń, szczególnie z katechetyki, homiletyki, liturgiki, duchowości, teologii pastoralnej i duszpasterstwa rodzin, „seminarzyści zdobywają wiedzę i wstępne umiejętności duszpasterskie, które mają być wykorzystane i pogłębione w trakcie praktyk duszpasterskich" (RISP 309). Według autorów dokumentu realizowane i weryfikowane zarówno w toku studiów, jak w czasie wakacji praktyki w środowiskach kościelnych i świeckich, dotyczące nie tylko liturgii i katechezy, ale ewangelizacji i służby bliźnim, mają pomóc klerykom w stopniowym, związanym z podejmowaniem właściwych zadań, zdobywaniu doświadczeń i umiejętności duszpasterskich oraz poznawaniu pragmatyki pracy w diecezji. Mają one także uczyć ich podejmowania coraz większej odpowiedzialności za powierzone im osoby oraz dzieła, jak też pracy indywidualnej i zespołowej. Podejmując cel praktyk, autorzy dokumentu nie tylko zwracają uwagę na zdobywanie konkretnych doświadczeń i umiejętności, ale podkreślają konieczność inicjowania przez seminarium procesu kształtowania wrażliwości pasterskiej, co wiąże się z przygotowywaniem do świadomego i dojrzałego przyjęcia odpowiedzialności oraz wyrabiania wewnętrznego nawyku „oceniania problemów, ustalania priorytetów i wyboru rozwiązań w świetle jednoznacznych nakazów wiary i zgodnie z teologicznymi wymogami samego duszpasterstwa" (RISP 311). Formacja pastoralna kandydatów do święceń ma im pomóc w wypracowaniu cech pożądanych u pasterzy Kościoła, szczególnie „umiejętność bycia kierownikiem i przewodnikiem grupy oraz umiejętność współpracy z wiernymi świeckimi, osobami życia konsekrowanego i diakonami stałymi” (RISP 310-311). Autorzy dokumentu zwracają też uwagę na konieczność 
przygotowania kandydatów do prezbiteratu w zakresie spotkań z ofiarami wykorzystania seksualnego i innych form przemocy oraz ich sprawcami (por. RISP 312).

Dużo wskazań dotyczących formacji teologicznopastoralnej znajduje się przy omawianiu etapu pastoralnego zwanego również etapem syntezy drogi ucznia-misjonarza. Obejmuje on okres między stałym pobytem w seminarium a święceniami prezbiteratu; podkreśla, że jednym $\mathrm{z}$ jego celów jest, przy zachowaniu kontynuacji linii formacyjnej poprzednich etapów, prowadzenie seminarzysty „do osiągania żywej syntezy formacji ludzkiej i duchowej, codziennego życia, posług pastoralnych, studium filozofii, nauk humanistycznych, teologii diakonatu i kapłaństwa” (RISP 323). Formacja intelektualna prowadzona na tym etapie ma pomagać kandydatom do święceń w zbudowaniu syntezy wiedzy zdobytej w czasie studiów oraz „nabyciu sprawności w jej stosowaniu w odniesieniu do problemów pastoralnych" (RISP 621). Edukacja obejmująca studium przedmiotów służących bezpośrednio posłudze kapłańskiej, uwzględniająca normy zawarte w Ratio oraz specyficzne potrzeby czasu i miejsca pracy duszpasterskiej, ma przygotowywać przyszłych prezbiterów do gorliwości misyjnej i odpowiedzi na wymagania nowej ewangelizacji (por. RISP 326-327). Autorzy dokumentu apelują o wychowywanie seminarzystów do uległości wobec Ducha Świętego, towarzyszenia duszpasterskiego różnym grupom i wspólnotom, korzystania ze środków społecznego przekazu, jak też stosowania zasad katolickiej nauki społecznej (por. RISP 327). Ukazując cel i istotę praktyk duszpasterskich realizowanych na tym etapie, podkreślają oni, że mają one przede wszystlkim dotyczyć ewangelizacji i pracy z grupami, zwracając uwagę na konieczność bezinteresownego przeżywania służby na wzór Chrystusa (por. RISP 319; 328). Predyspozycje pastoralne, wyrażające się w gotowości oddania życia Bogu i służenia Jemu w ludziach z miłością i mądrością, mają stanowić jedno z kryteriów branych pod uwagę przy ocenie zdatności kandydatów do święceń (por. RISP 348; 350).

Opis założeń formacji pastoralnoteologicznej, która ma się dokonywać na poszczególnych etapach prowadzących do święceń prezbiteratu, dobrze wskazuje na konieczność jej linearnego rozwoju. Harmonijnie połączono w nim różne wymiary formacji, wskazując na konieczność całościowej jej realizacji. Zauważa się, że jest to proces, którego konsekwentna 
realizacja może pomóc w realizacji zamierzonego celu formacji kapłana sprawującego swoją posługę na wzór Chrystusa Dobrego Pasterza.

\section{PROCES KSZTAŁCENIA W RAMACH FORMACJI PASTORALNOTEOLOGICZNEJ}

Szczególną rolę $\mathrm{w}$ formacji pastoralnoteologicznej pełni proces dydaktyczny $\mathrm{w}$ ramach jednolitych studiów magisterskich na wydziałach teologicznych, w tym uniwersyteckich podlegających Stolicy Apostolskiej (por. RISP 397). Realizacja procesu dydaktycznego charakterystycznego dla kształcenia uniwersyteckiego została przyjęta niezależnie od umiejscowienia tychże wydziałów ${ }^{6}$ (por. RISP 401). Dlatego swoistym novum w dokumencie jest uwzględnienie zarówno Europejskiego Systemu Transferu Punktów, jak i konieczności tworzenia sylabusów zawierających efekty uczenia się wraz ze wskazaniem sposobów ich weryfikacji (por. RISP 406; 409-419). Jest to pokłosie zmian w szkolnictwie wyższym, zapoczątkowanych w Europie przez Deklarację Sorbońską i Proces Boloński ${ }^{7}$, które zostały także przyjęte $\mathrm{w}$ Polsce ${ }^{8}$. W dokumentach państwowych teologia znajduje się w obszarze nauk humanistycznych, w dziedzinie nauk teologicznych'.

$\mathrm{W}$ ramach realizacji jednolitych studiów magisterskich $\mathrm{z}$ teologii powinien być uwzględniony nie tylko aspekt intelektualny, ale także ludzki, duchowy i duszpasterski (por. RISP 399-400; PDV 71), stąd konieczne jest współdziałanie nauczycieli akademickich z władzami seminaryjnymi (por. RISP 402-403). Autorzy Ratio zwracają uwagę zarówno na znacze-

6 Por. J. Kurosz, Kształcenie, s. 195.

7 Por. Deklaracja Bolońska. Szkolnictwo wyższe w Europie. Wspólna Deklaracja Europejskich Ministrów Edukacji, zebranych w Bolonii w dniu 19 czerwca 1999, w: Proces Boloński. Zbiór dokumentów. Konferencja Rektorów Uniwersytetów Polskich, Poznań 2004 s. 22-25, J. Kurosz, Ksztatcenie, s. 79-80.

${ }^{8}$ Por. Ustawa $z$ dnia 20 lipca 2018 roku. Prawo o szkolnictwie wyższym i nauce, Dz.U. 2018 poz. 1668.

9 Por. Załącznik do rozporządzenia Ministra Nauki i Szkolnictwa Wyższego z dnia 8 sierpnia 2011 roku. (poz. 1065), w: Rozporządzenie Ministra Nauki i Szkolnictwa Wyższego $z$ dnia 8 sierpnia 2011 roku w sprawie obszarów wiedzy, dziedzin nauki i sztuki oraz dyscyplin naukowych i artystycznych, Dz.U. $2011 \mathrm{nr} 179$ poz. 1065. 
nie pracy własnej studentów, jak i odpowiednią organizację procesu dydaktycznego (por. RISP 399; 401-403).

Charakterystycznymi formami kształcenia uniwersyteckiego przyjętymi przez autorów dokumentu są wykłady, ćwiczenia, konwersatoria, seminaria naukowe ${ }^{10}$ (por. RISP 412). W trakcie tych zajęć adepci nauki-klerycy są zobligowani do rzetelnego zdobycia wiedzy, odpowiednich umiejętności związanych z rozumieniem i interpretacją poznanych faktów, które pozwolą im lepiej pojmować świat i wykorzystywać zdobytą wiedzę zarówno w życiu codziennym, jak i w służbie eklezjalnej wspólnoty ${ }^{11}$.

Przed osobami zaangażowanymi $\mathrm{w}$ formację pastoralnoteologiczną stoi nie lada wyzwanie, gdyż w programie studiów filozoficzno-teologicznych przeznaczono jedynie 90 godzin na teologię pastoralną (por. RISP 424). Warto przypomnieć, że w Ratio institutionis sacerdotalis pro Polonia z 1999 roku liczba godzin przedmiotów pastoralnych (teologia pastoralna, liturgika, muzyka kościelna, homiletyka, fonetyka) wynosiła $532^{12}$, zaś w obecnym dokumencie pomniejszono o 112 godzin liczbę zajęć dydaktycznych z tych przedmiotów (por. RISP 424). Dlatego zapewne autorzy dokumentu zamieścili uwagę skierowaną do osób układających programy studiów na poszczególnych wydziałach, która dotyczyła kolejności owych przedmiotów, np. zajęcia z teologii pastoralnej powinny się rozpocząć dopiero po zaliczeniu przez studentów eklezjologii dogmatycznej (por. RISP 526). Jest to bardzo istotne, gdyż pierwszym i podstawowym wyznacznikiem kształcenia pastoralnoteologicznego jest eklezjologia Soboru Watykańskiego II będąca zbiorową refleksją całego Kościoła nad samym sobą i sposobami jego urzeczywistniania ${ }^{13}$. W założeniach teoretycznych takie posunięcie wydaje się logiczne, ale pojawiają się wątpliwości związane z realizacją tego postulatu. Dotyczą one możliwości uwzględnienia kolejności tych przedmiotów w programie studiów i zakresu materiału, gdyż eklezjologię połączono z charytologią oraz mariologią i przeznaczono na ten blok tematyczny jedynie 45 godzin dydak-

10 Por. J. Kurosz, Kształcenie, s. 206-2013.

11 Por. tamże, s. 204

12 Por. Konferencja Episkopatu Polski, Ratio institutionis sacerdotalis pro Polonia. Zasady formacji kapłańskiej w Polsce, Częstochowa 1999, s. 141. Dziwić może fakt, że zajęcia $\mathrm{z}$ katechetyki zostały umieszczone w bloku przedmioty psychologiczno-pedagogiczno-katechetyczne.

13 R. Kamiński, Formacja, s. 102. 
tycznych (por. RISP 424; 502; 505). Pozostaje mieć nadzieję, że wytyczne z Ratio zostaną z należytą starannością zastosowane.

W formacji pastoralnoteologicznej szczególnie ważne jest powiązanie wymiaru intelektualnego z kształtowaniem świadomości oraz postawy eklezjalnej kleryków (por. RISP 98). Wiedza teoretyczna przekazywana podczas wykładów, choć niezmiernie istotna, nie ma mocy sprawczej w tym względzie. Potrzebny jest czas na namysł i dialog między wykładowcami i studentami prowadzący do zrozumienia istoty Kościoła, sposobów jego urzeczywistniania, a przede wszystkim do wypracowania określonych umiejętności. W kształceniu akademickim dokonuje się on w ramach ćwiczeń, konwersatoriów, seminariów naukowych. Właśnie ta grupa zajęć dydaktycznych nie została należycie uwzględniona przez autorów Ratio. Mimo to trzeba wyraźnie zaznaczyć, że „podstawowym źródłem wiedzy w procesie kształcenia dorosłych jest słuchanie" ${ }^{14}$, a wykład należy do najbardziej znanych i pospolitych form kształcenia uniwersyteckiego. Istnieje jednak niebezpieczeństwo utrwalenia wśród studentów swoistej bierności, przejawiającej się $\mathrm{w}$ zaniechaniu twórczej pracy, nadmiernego werbalizmu i abstrakcyjności, a przede wszystkim oderwania wiedzy od wymiaru praktycznego ${ }^{15}$. Warto $\mathrm{w}$ tym miejscu wspomnieć o różnicy procentowej między ćwiczeniami a wykładami z teologii pastoralnej, która wynosi $50 \%$ w porównaniu z 69,23\% w ramach katechetyki i przygotowania pedagogicznego. Zwiększona liczba ćwiczeń w tej grupie przedmiotów jest pokłosiem obowiązującego rozporządzenia z 2019 roku określającego standardy kształcenia przygotowujące do wykonywania zawodu nauczyciela ${ }^{16}$. Zmieniające się uwarunkowania społeczne mające wpływ na kształcenie młodego pokolenia wymusiło niejako zmiany w przygotowaniu nauczycieli do wykonywania ich zawodu. Tematyka 135 godzin ćwiczeń z grupy przedmiotów katechetycznych może w pewnym zakresie być pomocna w pracy duszpasterskiej. Nie zmienia to jednak faktu zmniejszonej do 30 godzin tego typu zajęć dydaktycznych z teologii pastoralnej, które mają

14 J. Półturzycki, Dydaktyka dorosłych, Warszawa 1991, s. 181.

15 Por. J. Kurosz, Kształcenie, s. 207; W. Okoń, Elementy dydaktyki szkoły wyższej, Warszawa 1991, s. 179.

16 Por. Rozporzadzenie Ministra Nauki Szkolnictwa Wyższego $z$ dnia $z$ dnia 25 lipca 2019 r. w sprawie standardu ksztatcenia przygotowującego do wykonywania zawodu nauczyciela, Dz.U. 2019 poz. 1450. 
mieć wkład w ugruntowanie wiedzy i umiejętności stanowiących podstawę do przyszłej pracy duszpasterskiej. Realizacja efektów kształcenia w tak zaproponowanej siatce godzin jest po prostu niemożliwa. Celowo w tym miejscu pomijamy zagadnienie praktyk duszpasterskich (por. RISP 99), które mają inną specyfikę, choć ich owocność zależy od wcześniej nabytej wiedzy i umiejętności przez studentów. Powiązania między tymi formami kształcenia domagają się bardziej szczegółowych analiz w tym zakresie i zaproponowania konkretnych rozwiązań.

Wykładowcy zajęć dydaktycznych z zakresu teologii pastoralnej mają wprowadzić kleryków w świat tej dyscypliny oraz dążyć „do naukowego ukształtowania świadomości istoty i zbawczego posłannictwa aktualnie działającego Kościoła, który realizuje w konkretnych warunkach w swoją misję zbawczą" (RISP 523). Kluczową kwestią w formacji będzie więc przekazanie wiedzy dotyczącej specyfiki teologii pastoralnej będącej dyscypliną naukową i kształtowania umiejętności odróżnienia jej od pastoralnych aspektów całej teologii oraz dostrzeżenia jej służebnej roli wobec wspólnoty Kościoła (por. RISP 523; 527). Teologia pastoralna jest w szczególny sposób narażona na marginalizację jej charakteru naukowego i sprowadzenie jej jedynie do wymiaru praktycznego, pozbawionego refleksji naukowej. Dlatego przeznaczenie 15 godzin wykładu na zajęcia $\mathrm{z}$ teologii pastoralnej fundamentalnej wydaje się niewystarczające do osiągnięcia zamierzonego celu. Wprawdzie studenci muszą samodzielnie opanować część wiedzy, ale w tym miejscu pojawia się pytanie o jej jakość, a zwłaszcza trwałość i umiejętność korzystania z niej, która w pewnym stopniu kształtuje się podczas wykładów ${ }^{17}$. Ten typ zajęć dydaktycznych jest obecny na większości wydziałów w blokach półtoragodzinnych, stąd rodzi się pytanie o faktyczną ich liczbę, istnieje bowiem obawa, że niewielki czas przeznaczony na teologię pastoralną fundamentalną zostanie w praktyce jeszcze bardziej okrojony.

Poruszana kwestia jest szczególnie istotna, gdyż w ramach prezentowanej formacji studenci mają kształtować swój sposób myślenia pastoralnoteologicznego, poznając teologiczne zasady urzeczywistniania się Kościoła, „ucząc się naukowego odczytywania oraz interpretowania „znaków czasu” i rozeznawania zastanej sytuacji społeczno-kulturowej

17 Por. J. Kurosz, Kształcenie, s. 207. 
i religijnej, aby następnie rozwiązywać konkretne problemy duszpasterskie" (RISP 523). Przy czym, jak wskazują autorzy dokumentu, nie chodzi o tzw. reakcję będącą odpowiedzią na pojawiające się wyzwania. Istotniejsze jest ukształtowanie metody rozwiązywania problemów duszpasterskich w sposób systemowy we współpracy z innymi dyscyplinami naukowymi, które następnie będą odpowiednio realizowane na różnych poziomach eklezjalnej wspólnoty. Takie postrzeganie formacji wynika $\mathrm{z}$ interdyscyplinarnego charakteru teologii pastoralnej (por. RISP 523-524), ale jej trwały sukces zależy od ugruntowania w świadomości jej uczestników podstaw tej nauki.

Kolejnym ważnym aspektem formacji jest przygotowanie przyszłych kapłanów do współpracy z laikatem oraz członkami stowarzyszeń i instytutów życia konsekrowanego. Wynika ona z istoty Kościoła, który jest wspólnotą, dlatego eklezjologia komunii powinna stanowić fundament zarówno działań w omawianym zakresie zajęć na wydziałach teologicznych, jak i przyszłej pracy duszpasterskiej. Zaproponowana w Ratio tematyka w ramach wykładów i ćwiczeń z teologii pastoralnej szczegółowej umożliwia w pewnym wymiarze realizację tego celu (por. RISP 528). Z kolei wykorzystanie potencjału naukowego świeckich i osób konsekrowanych w trakcie studiów teologicznych w naturalny sposób utrwala postawy otwartości na ową współpracę. Autorzy dokumentu zwracają też uwagę na konieczność przygotowania studentów do zmieniających się uwarunkowań działalności duszpasterskiej Kościoła. Ma się ono dokonywać poprzez kształtowanie postawy nawrócenia pastoralnego już na etapie formacji, na które zwrócił uwagę papież Franciszek ${ }^{18}$, oraz ewangelicznego stylu słuchania (por. RISP 524). Przekonanie adeptów nauki do wypracowania w sobie kreatywności połączonej z wiedzą oraz namysłem pastoralnym, a przede wszystkim otwartości zarówno na współbraci $\mathrm{w}$ wierze, jak osób niewierzących to jedno z wielu wyzwań, z jakim muszą się zmierzyć zarówno wykładowcy, jak i klerycy.

Duszpasterstwo rodzin jako osobny przedmiot był nieobecny w poprzednich dokumentach normujących formację przyszłych prezbiterów. Do tej pory zakres tematyczny był realizowany w ramach teologii pastoralnej szczegółowej lub podczas wykładów monograficznych. Autorzy oma-

18 Por. Franciszek, Adhortacja apostolska Evangelii gaudium, Watykan 2013, nr 15; 33 (dalej skrót: EG). 
wianego Ratio przeznaczyli na ten przedmiot względnie dużo zajęć - 15 godzin wykładowych i 15 godzin ćwiczeń, w stosunku do teologii pastoralnej fundamentalnej - 15 godzin wykładów, teologii pastoralnej szczegółowej 30 godzin wykładów i 15 godzin ćwiczeń (por. RISP 526-528). Z pewnością inspirowali się wskazaniami zawartymi w adhortacji Franciszka Amoris leatitia mówiącymi o konieczności ukierunkowania duszpasterstwa na rodzinę i właściwego, interdyscyplinarnego przygotowania kleryków do tej posługi ${ }^{19}$. Obserwowany kryzys rodziny, który dosięgnął także ludzi ochrzczonych, stanowi ogromne wyzwanie dla całego Kościoła, czego swoistym elementem odpowiedzi jest wprowadzenie do formacji seminaryjnej obowiązkowego przedmiotu. Nie negując znaczenia konieczności przygotowania kapłanów do nowych wyzwań, zwłaszcza w tym aspekcie, pojawiają się wątpliwości dotyczące uwarunkowań realizacji tego przedmiotu, jak i jego znaczenia dla przyszłej pracy duszpasterskiej. Trzeba podkreślić, że prowadzenie tych zajęć powinno się rozpocząć po sakramentologii dogmatycznej (por. RISP 529) oraz, co wydaje się logiczne, choć nie jest to podkreślone w Ratio, po eklezjologii, teologii pastoralnej fundamentalnej i szczegółowej. Takie rozwiązanie w większym stopniu gwarantuje osiągniecie zamierzonych celów formacji pastoralnoteologicznej, gdyż duszpasterstwo rodzin nie może być oderwane od teologicznej wizji całej pracy duszpasterskiej Kościoła. Trzeba też zadbać o to, aby przedmiot ten wykładali dobrze do tego przygotowani specjaliści, pokazujący konieczność interdyscyplinarnego podejścia do tematyki małżeństwa i rodziny. Warto przy tym zauważyć, że w Ratio zamieszczono wiele uwag związanych z uwarunkowaniami związanymi ze sposobem wykładania różnych przedmiotów, co sprawia, że realizacja wielu zaleceń może okazać się bardzo utrudniona lub, w niektórych sytuacjach, wręcz niemożliwa. Istnieje także uzasadniona obawa, że czas przeznaczony na duszpasterstwo rodzin nie przyniesie oczekiwanych rezultatów ze względu na zbyt małą ilość godzin przeznaczonych na ugruntowanie wiedzy oraz umiejętności z zakresu teologii pastoralnej fundamentalnej. Jednak w tym momencie są to jedynie przypuszczenia, które zweryfikuje przyszłość.

Formacja pastoralnoteologiczna jest realizowana także w ramach dyscyplin należących do działu teologii praktycznej-liturgiki, katechety-

19 Por. Franciszek, Adhortacja apostolska Amoris leatitia, Watykan 2016, nr 202-203. 
ki, homiletyki oraz jest ściśle powiązana z innymi dyscyplinami naukowymi. Autorzy Ratio zalecili obowiązkowe przedmioty z edukacji medialnej (por. RISP 590-591) i socjologii (por. RISP 588-589), których wybrane zagadnienia mieszczą się także $\mathrm{w}$ ramach problemów poruszanych przez teologię pastoralną. Dzięki temu studenci w trakcie nauki mają szerszą perspektywę omawianych kwestii. Proces kształcenia ukierunkowany na całościowe przedstawienie zagadnień $\mathrm{w}$ ramach różnych przedmiotów wymaga ścisłej współpracy wszystkich wykładowców, co w pewnym wymiarze było do tej pory realizowane, choć w niewystarczający sposób. Obecnie realizacja programów studiów opracowanych według wytycznych zawartych w nowym Ratio ma być obowiązkowa (por. RISP 402), co wymusi konieczność korelacji przedmiotów i zapewne zmiany nastawienia wykładowców do procesu kształcenia.

W procesie formacji na etapie pastoralnym będą obligatoryjnie realizowane przedmioty zawierające pastoralne aspekty teologii (por. RISP 620-621). Wśród niech znalazły się filozoficzno-światopoglądowe konteksty współczesnej ewangelizacji, psychologia pastoralna, synteza teologii, ewangelizacja kerygmatyczna, organizacja życia diecezjalnego (por. RISP 624; 627; 630-631; 635). Ponadto zaproponowano w tym czasie zajęcia dotyczące posługi charytatywnej wobec chorych i umierających (por. RISP 637-639), zagadnień z socjologii religii i kultury oraz duszpasterstwa młodzieży (por. RISP 641-643). Tematyka wchodząca w zakres niektórych przedmiotów była do tej pory prezentowana $\mathrm{w}$ ramach teologii pastoralnej szczegółowej, co rodzi dodatkowe problemy podczas układania nowych programów. Poza tym w dobie wielorakich zagrożeń i zmieniających się uwarunkowań współczesnego świata pojawia się pytanie o kryteria wyboru wskazanych zagadnień.

Praktyki duszpasterskie w ramach formacji pastoralnoteologicznej mają na celu zarówno zweryfikowanie wiedzy i umiejętności nabytych podczas studiów, jak i systematyczne kształtowanie odpowiedzialności pastoralnej dokonującej się poprzez konfrontowanie kleryków ze specyficznymi problemami przyszłej posługi. Nie bez znaczenia pozostaje zdobycie doświadczeń i kompetencji duszpasterskich oraz poznanie pragmatyki pracy nie tylko we wspólnotach kościelnych. Jest to szczególny czas odkrywania potencjału tkwiącego w seminarzystach oraz ich niedostatków, z którymi mierzą się w codzienności. Autorzy Ratio wskazują różne 
miejsca przebiegu praktyk w zależności od etapu formacji przy zachowaniu pierwszeństwa parafii (por. RISP 99-102; 294; 310-312), zaś realizowane cele pozostają w ścisłej zależności od poszczególnych etapów formacji, przy jednoczesnym zastosowaniu zasady stopniowania trudności (por. RISP 319-323; 328-329). Wielkim wyzwaniem staje się zagadnienie dobrego zaplanowania praktyk duszpasterskich, przygotowania alumnów do ich przeprowadzenia, ich zrealizowanie oraz ewaluacja. Dużą rolę do odegrania ma w tym względzie koordynator formacji duszpasterskiej, który ma zająć się koordynacją teoretycznego i praktycznego przygotowania duszpasterskiego seminarzystów, ustalając z prezbiterami, osobami życia konsekrowanego i wiernymi świeckimi odpowiednie miejsce stażu duszpasterskiego oraz organizując praktyki dla poszczególnych alumnów (por. RISP 186).

Formacja pastoralnoteologiczna realizowana $\mathrm{w}$ ramach nowych programów studiów teologicznych uwzględniających zalecenia zawarte w Ratio ma się przyczynić do kształtowania głębokiej świadomości adeptów nauki - kleryków w tym zakresie. Czas pokaże, czy okres formacji będzie miał odzwierciedlenie w ich przyszłej posłudze duszpasterskiej na rzecz eklezjalnej wspólnoty, uwzględniającej „znaki czasu”.

\section{PODSUMOWANIE}

Trzeba zauważyć, że nowe Ratio dużo miejsca poświęca kwestii formacji pastoralnoteologicznej. Nachylenie pastoralne całej formacji seminaryjnej jest jedną z wiodących myśli przewijających się przez cały dokument. Takie ujęcie omawianego zagadnienia, podkreślające konieczność duszpasterskiego ukierunkowania całej drogi formacyjnej kandydatów do kapłaństwa, dobrze wpisuje się w nauczanie soborowe rozwinięte przez Jana Pawła II, mówiące o ich przygotowywaniu do udziału w miłości Chrystusa Dobrego Pasterza (por. DFK 19; PDV 57). Koreluje to także z wezwaniem Franciszka skierowanym do teologów o pełnieniu przez nich swojej posługi w kontekście realizacji ewangelizacyjnego celu Kościoła, który ma podążać drogą duszpasterskiego i misyjnego nawrócenia (por. EG 25; 133). 
Autorzy artykułu mają świadomość, że w tego typu opracowaniu nie sposób w całościowy i pogłębiony sposób podjąć wszystkich aspektów związanych z formacją pastoralnoteologiczną kleryków. Postanowili zwrócić uwagę na niektóre $\mathrm{z}$ nich, aby rozpocząć, realizowaną w duchu synodalności, dyskusję nad sposobem jej urzeczywistniania. Pragną zaznaczyć, że ich przewidywania nie muszą znaleźć potwierdzenia podczas realizowanej formacji. Zgłoszone przez nich głosy krytyczne wynikają z ich troski o dobro całej wspólnoty Kościoła i jak najlepsze przygotowanie kandydatów do kapłaństwa i realizacji przez nich swojego powołania do misji Dobrego Pasterza.

Pragnąc dostarczyć rzeczowych przesłanek do merytorycznej dyskusji dotyczącej formacji pastoralnoteologicznej kleryków, planują oni także przygotowania kolejnych artykułów, w których szczegółowo podejmą kwestie praktycznego sposobu korelacji treści przekazywanych w ramach różnych wykładów, prowadzenia ćwiczeń czy odbywania praktyk duszpasterskich. Chcą także zająć się kwestią pastoralnoteologicznej formacji tych adeptów nauki studiujących teologię, których studia nie są związane z przygotowywaniem do przyjęcia święceń prezbiteratu, ale pragną pełnić posługę teologów świeckich lub nauczać lekcji religii. Zapraszają oni do dyskusji wszystkich odpowiedzialnych za formację pastoralnoteologiczną kleryków na temat sposobów jej realizacji tak, aby jak najlepiej formować uczniów-misjonarzy służących Bogu, Kościołowi i wszystkim bez wyjątku ludziom.

\section{BIBLIOGRAFIA}

Deklaracja Bolońska. Szkolnictwo wyższe w Europie. Wspólna Deklaracja Europejskich Ministrów Edukacji, zebranych w Bolonii w dniu 19 czerwca 1999, w: Proces Boloński. Zbiór dokumentów. Konferencja Rektorów Uniwersytetów Polskich, Poznań 2004, s. $22-25$.

Droga formacji prezbiterów w Polsce. Ratio institutionis sacerdtotalis pro Polonia, Warszawa 2021, https://episkopat.pl/wp-content/uploads/2021/06/20210616Droga-formacji-prezbiterów-w-Polsce.pdf (data dostępu: 25.07.2021).

Benedykt XVI, Przemówienie do uczestników sympozjum teologicznego zorganizowanego przez Kongregację ds. Duchowieństwa Kapłaństwo wymaga radykalnej ciągłości między formacją seminaryjna a formacja stała, Watykan 12.03.2010, „L'Osservatore Romano" 5 (2010), s. 35-36. 
Franciszek, Adhortacja apostolska Amoris leatitia, Watykan 2016.

Franciszek, Adhortacja apostolska Evangelii gaudium, Watykan 2013.

Jan Paweł II, Adhortacja apostolska Pastores dabo vobis, Watykan 1992.

Konferencja Episkopatu Polski, Ratio institutionis sacerdotalis pro Polonia. Zasady formacji kapłańskiej w Polsce, Częstochowa 1999.

Kurosz J., Kształcenie pastoralne na uniwersyteckich wydziałach teologicznych, Poznań 2018.

Okoń W., Elementy dydaktyki szkoły wyższej, Warszawa 1991.

Półturzycki J., Dydaktyka dorosłych, Warszawa 1991.

Rozporządzenie Ministra Nauki Szkolnictwa Wyższego z dnia z dnia 25 lipca 2019 r. w sprawie standardu kształcenia przygotowującego do wykonywania zawodu nauczyciela, Dz.U. 2019 poz. 1450.

Sobór Watykański II, Dekret o soborowej formacji kapłańskiej Optatam totius, Watykan 1965.

Ustawa z dnia 20 lipca 2018 roku. Prawo o szkolnictwie wyższym i nauce, Dz.U. 2018 poz. 1668.

Załąznik do rozporządzenia Ministra Nauki i Szkolnictwa Wyższego z dnia 8 sierpnia 2011 roku. (poz. 1065), w: Rozporządzenie Ministra Nauki i Szkolnictwa Wyższego $z$ dnia 8 sierpnia 2011 roku. w sprawie obszarów wiedzy, dziedzin nauki i sztuki oraz dyscyplin naukowych i artystycznych, Dz.U. 2011 nr 179 poz. 1065. 